\title{
RELEVANSI BUKU PENDIDIKAN AGAMA ISLAM TERBITAN YAMIBA DENGAN KURIKULUM 2013
}

\section{RELEVANCE OF ISLAMIC STUDIES BOOK PUBLISHED BY YAMIBA WITH THE 2013 CURRICULUM}

\author{
Munawiroh \\ Puslitbang Pendidikan Agama dan Keagamaan \\ Badan Litbang dan Diklat Kemenag \\ Jl. MH Thamrin No. 6 Jakarta Pusat \\ mun.asrori@gmail.com
}

Naskah diterima 20 April 2017, direvisi 10 Mei 2017, disetujui 17 Juli 2017

\begin{abstract}
Textbooks that have been assessed by $a$ Team, should have met academic requirements with regard to competence, learning process, and assessment and change of the 2013 curriculum paradigm. Based on the criteria of PAI textbooks on this PTU, this paper investigates in more detail the content presented in accordance with the demands of the 2013 Curriculum that can be categorized that this textbook is relevant to the learning process in PTU. This study uses qualitative approach with textbook as its subject. Meanwhile, the research method is descriptive, with the intent to describe, analyze and interpret the content of the research subject, namely PAI Books published by Yamiba PTU Publisher Jakarta. The result of this study concludes that this book is relevant to the 2013 curriculum, which refers to the student's competence on the aspects of attitude, knowledge, and skills implemented in al-akhlak al-karimah while in the process of learning, this book focuses on students (student centered learning).
\end{abstract}

Keywords : Relevance, Islamic Studies Book, General Higher Education, The 2013 Curriculum.

\begin{abstract}
Abstrak
Buku teks yang telah dinilai sebuah Tim, semestinya telah memenuhi persyaratan secara akademis baik secara kompetensi, proses pembelajaran, dan penilaian serta perubahan paradigma kurikulum 2013. Berdasarkan kriteria buku teks PAI pada PTU ini, tulisan ini mengetahui lebih rinci muatan atau materi yang disajikan sesuai dengan tuntutan Kurikulum 2013 yang dapat dikategorikan bahwa buku teks ini memiliki relevansi dengan proses pembelajaran di PTU. Studi ini menggunakan pendekatan kualitatif dengan dokumen buku teks sebagai subjeknya. Sedangkan metode penelitiannya yaitu metode deksriptif, dengan maksud untuk mendeksripsikan, menganalisis dan menginterpretasi content subjek penelitian yaitu Buku PAI pada PTU Penerbit Yamiba Jakarta. Hasil studi ini menyimpulkan bahwa buku ini memiliki relevansi dengan kurikulum 2013, yang mengacu pada kompetensi mahasiswa pada aspek sikap, pengetahuan, dan keterampilan yang implementasinya ada dalam al-akhlak al-karimah. Sementara dalam proses pembelajarannya buku ini berpusat pada mahasiswa (student centered learning).
\end{abstract}

Kata Kunci : Relevansi, Buku PAI, Perguruan Tinggi Umum, Kurikulum 2013 


\section{PENDAHULUAN}

Mata kuliah Pendidikan Agama Islam (PAI) pada Perguruan Tinggi Umum (PTU) memiliki peran sangat strategis dalam mencapai luaran (learning outcome) mahasiswa yang beriman, bertakwa, dan berakhlak mulia serta melekat ketika mahasiswa tersebut terjun pada dunia profesi dan masyarakat. Kepribadian Islami dari mahasiswa merupakan implementasi setelah mengikuti perkuliahan PAI.

Peran strategis mata kuliah PAI itu sejalan dengan tujuan pendidikan nasional Indonesia sebagaimana ditegaskan dalam Undang-Undang Nomor 20 Tahun 2003 tentang Sistem Pendidikan Nasional Bab II Pasal 3 bahws: pendidikan nasional bertujuan untuk berkembangnya potensi peserta didik agar menjadi manusia yang beriman dan bertakwa kepada Tuhan Yang Maha Esa, berakhlak mulia, sehat, berilmu, cakap, kreatif, mandiri dan menjadi warga negara yang demokratis serta bertanggung jawab. Tujuan mata kuliah PAI pada PTU merupakan bagian integral dari tujuan pendidikan nasional.

Dalam pencapaian tujuan itu, keberhasilan mata kuliah PAI pada PTU dipengaruhi oleh berbagai faktor. Salah satu faktor penting itu adalah proses pembelajaranatau perkuliahan. Adanyabuku teks dapat mendorong terselenggaranya suatu pembelajaran atau perkuliahan yang berkualitas. Buku merupakan referensi yang sampai saat ini masih memiliki posisi yang urgen walaupun kini telah berkembang pesat referensi-referensi digital. Berkaitan dengan itu, adanya buku ajar dalam suatu proses pembelajaran atau perkuliahan mutlak diperlukan.
Banyaknya buku ajar PAI yang beredar di lapangan tentu harus direspon secara positif. Tentunyadapat memperkaya hazanah mahasiswa dalam menemukan berbagai materi yang diperlukan. Namun adanya buku dengan standar kurikulum yang berlaku merupakan kebutuhan yang sangat diperlukan. Dalam suatu kebijakan berlakunya kurikulum paling tidak di dalamnya terdapat komponen kompetensi (learning outcome) yang harus dimiliki subjek belajar (mahasiswa), pembelajaran, dan penilaian. Berkaitan dengan itu, maka buku ajar yang baik paling tidak memuat ketiga komponen.

Komponen kompetensi (learning outcome) merupakan seperangkat yang harus dimiliki mahasiswa setelah mengikuti proses pembelajaran atau perkuliahan. Kompetensi yang dimaksud adalah aspek pengetahuan, sikap, dan keterampilan. Komponen pembelajaran merupakan suatu proses yang ditempuh untuk mencapai tujuan yang telah ditetapkan (kompetensi yang harus dimiliki subjek belajar). Proses pembelajaran yang baik adalah proses dimana subjek belajar (mahasiswa) aktif membangun pengetahuan secara mandiri, sehingga menjadi sikap dan mengimplementasikannya dalam perilaku.

Komponen penilaian merupakan suatu proses untuk memperoleh datadata mengenai pengetahuan, sikap, dan perilaku subjek belajar (mahasiswa) setelah mengikuti proses pembelajaran. Penilaian yang baik tentunya harus mengacu ketiga aspek itu. Berkaitan dengan itu, kurikulum 2013 merupakan pengembangan dari kurikulum sebelumnya untuk merespon berbagai tantangan internal dan eksternal. Implementasi Kurikulum 2013 dipandang merupakan langkah strategis dalam 
menghadapi globalisasi dan tuntutan masyarakat Indonesia masa depan.

Perubahan yang sangat mendasar pada kurikulum 2013 adalah materi disusun seimbang mencakup kompetensi sikap, pengetahuan, dan keterampilan. Pendekatan pembelajaran berdasarkan pengamatan, pertanyaan, pengumpulan data, penalaran, dan penyajian hasilnya melalui pemanfaatan berbagai sumber-sumber belajar (peserta didik mencari tahu), dan penilaian otentik pada aspek kompetensi sikap, pengetahuan, dan keterampilan berdasarkan portofolio. ${ }^{1}$

Buku Pendidikan Agama Islam PTU yang disusun Dr. Ali Hamzah, M.Ag hadir sebagai buku teks mata kuliah PAI pada PTU. Hal menarik dalam buku ini bahwa pada cover bawah terdapat tulisan: "Melalui Tim Pengembangan Kurikulum PAI di Perguruan Tinggi Umum 2014/2015)." Selain itu, menurut keterangan Penulis bahwa buku ini disusun berdasarkan kurikulum 2013.

Berdasar pada uraian tentang komponen yang harus ada yakni kompetensi, proses pembelajaran, dan penilaian serta perubahan paradigma kurikulum 2013 yang menekankan pada kompetensi (sikap, pengetahuan, dan keterampilan), proses pembelajaran dengan berpusat pada peserta didik sebagai subjek belajar, dan penilaian yang otentik menyeluruh pada ketiga aspek, maka Buku Pendidikan Agama Islam PTU yang disusun oleh Ali Hamzah tentu harus memuat komponen-komponen itu. Inilah pijakan peneliti untuk melakukan penelitian

${ }^{1}$ Direktorat Jenderal Pendidikan Islam Direktorat Pendidikan Agama Islam Kementerian Agama. 2014. Pedoman Umum Implementasi Kurikulum 2013 Pendidikan Agama Islam dan Budi Pekerti pada Sekolah Dasar (SD), Jakarta: Dirjen PAIS Kemenag RI, h. 10. lebih lanjut tentang relevansi buku ini dengan kurikulum 2013.

\section{Kerangka Konseptual}

\section{Relevansi Buku}

Dalam Kamus Besar Bahasa Indonesia relevansi adalah hubungan atau kaitan. Merelevansi berarti mempunyai relevansi. ${ }^{2}$ Kaitan di sini mengandung makna adanya hal yang dikonfirmasi dengan suatu hal lain sebagai subjek pengkonfirmasi. Suatu hal untuk mengkonfirmasi itu tentu harus memiliki instrumen-instumen konfirmasi. Dengan intrumen itu, antara satu hal setelah dikonfirmasikan dengan hal lainnya diperoleh deskripsi relevansinya.

Dalam penelitian ini subjek yang direlevansi adalah buku teks. Dalam Tarigan dikemukakan pengertian buku teks menurut para ahli. Buckingham mengemukakan buku teks adalah sarana belajar yang biasa digunakan di sekolah-sekolah dan di perguruan tinggi untuk menunjang suatu program pengajaran. Sedangkan menurut Bacon, buku teks adalah bukuyang dirancang untuk penggunaan di kelas, dengan cermat disusun dan disiapkan oleh para pakar atau ahli dalam bidang itu dan diperlengkapi dengan sarana-sarana pengajaran yang sesuai dan serasi. ${ }^{3}$

Dari pendapat beberapa ahli tersebut maka dapat disimpulkan bahwa buku teks memiliki arti berikut: (1) merupakan kumpulan ide dan gagasan para ahli, (2) ide dan gagasan itu disusun secara sistematis

${ }^{2}$ Kbbi.web.id/relevansi, Pengertian Relevansi, Diakses 17 Desember 2015.

${ }^{3}$ Henry Guntur Tarigan. 1986. Menulis sebagai Suatu Keterampilan Berbahasa, Bandung: Angkasa, h. 11. 
dan rasional suatu bidang keilmuan tertentu, (3) dipergunakan dalam kerangka pembelajaran, dan (4) sebagai sumber belajar dalam mendukung proses pembelajaran yang berkualitas sehingga dapat mencapai tujuan pembelajaran yang telah ditetapkan.

\section{Pendidikan Agama Islam pada PTU dalam Kurikulum 2013}

Marimba mengartikan pendidikan Islam sebagai bimbingan jasmani, rohani berdasarkan hukum-hukum Islam menuju kepada terbentuknya kepribadian utama. ${ }^{4}$ Sedangkan Al-Ghulayaini mengatakan bahwa pendidikan Islam ialah menanamkan akhlak yang mulia di dalam jiwa anak dalam masa pertumbuhannya dan menyiraminya dengan air petunjuk dan nasehat, sehingga akhlak itu menjadi salah satu kemampuan (meresap dalam) jiwanya kemudian buahnya berwujud keutamaan, kebaikan, dan cinta bekerja untuk kemanfaatan tanah air. ${ }^{5}$

Secara khusus tentang pendidikan agama Islam, Daradjat mengartikan sebagai suatu usaha untuk membina dan mengasuh peserta didik agar senantiasa dapat memahami ajaran Islam secara menyeluruh. Lalu menghayati tujuan, yang pada akhirnya dapat mengamalkan serta menjadikan Islam sebagai pandangan hidup. ${ }^{6}$

Pengertian-pengertian di atas, pada dasarnya mengandung pengertian yang sama, meskipun susunan bahasanya berbeda. Dengan demikian dapat

${ }^{4}$ Ahmad D. Marimba.1968. Pengantar Filsafat Pendidikan Islam, (Bandung: Al-Ma'arif, , h. 19.

${ }^{5}$ Nur Uhbiyati. 2005.Ilmu Pendidikan Islam, (Bandung: Pustaka Setia, 1997), h. 10.

${ }^{6}$ Abdul Majid dan Dian Andayani, Pendidikan Islam Berbasis Kompetensi,Bandung: Remaja Rosda Karya, hlm. 130. disimpulkan bahwa pendidikan agama Islam adalah bimbingan dan usaha yang diberikan kepada seseorang dalam pertumbuhan jasmani dan rohani menuju pada tingkat membentuk kepribadian yang utama, yaitu kepribadian muslim yang taat akan perintah dan menjauhi larangan Allah dalam rangka mencapai kebahagiaan hidup di dunia dan akhirat.

Di PTU, secara faktual PAI merupakan salah satu mata kuliah yang tergabung dalam kelompok Matakuliah Pengembangan Kepribadian $\quad(\mathrm{MPK})^{7}$. Pengembangan kepribadian manusia Indonesia yang berwawasan religius, berwawasan kebangsaan, peradaban dan kebudayaan Indonesia adalah hal sangat penting untuk dilaksanakan dalam rangka mencapai tujuan pendidikan nasional, yaitu untuk mengembangkan potensi peserta didik agar menjadi manusia yang beriman dan bertakwa terhadap Tuhan Yang Maha Esa, berakhlak mulia, sehat, berilmu, cakap, kreatif, mandiri dan menjadi warga negara yang demokratis dan bertanggung jawab. ${ }^{8}$

Peranan PAI dalam mencapai tujuan pendidikan nasional adalah sangat

${ }^{7}$ Mata Kuliah Pengembangan Kepribadian (MPK) adalah mata kuliah wajib nasional diberikan pada setiap Perguruan Tinggi Umum (PTU) di Indonesia, sebagaimana Undang-undang Nomor 20 Tahun 2003 tentang Sistem Pendidikan Nasional, dan dalam SK Dirjen Pendidikan Tinggi Nomor 43 tahun 2006 tentang rambu-rambu kelompok MPK yang terdiri dari mata kuliah: (1) Pendidikan Agama (sesuai dengan agama masing-masing). (2) Pendidikan Kewarganegaraan. (3) Bahasa. Lebih lanjut lihat Surat Keputusan Direktorat Jenderal Pendidikan Tinggi Departemen Pendidikan Nasional (Depdiknas) Nomor 43, Tahun 2006, Tentang Rambu-Rambu Pelaksanaan Kelompok Mata Kuliah Pengembangan Kepribadian di Perguruan Tinggi. h. 1.

${ }^{8}$ Undang-Undang Nomor 20 Tahun 2003 tentang Sistem Pendidikan Nasioanl, Bab IV, Pasal 9. 
strategis, karena tujuan PAI merupakan bagian integral dari tujuan pendidikan nasional. Konsekuensi logisnya, bahwa tujuan pendidikan nasional akan tercapai di perguruan tinggi apabila tujuan pendidikan Agama Islam telah dicapai terlebih dahulu.

Dalam perkembangannya, pencapaian tujuan PAI di PTU dihadapkan pada beberapa persoalan. Kesatu, pendidikan agama saat ini lebih berorientasi pada belajar tentang ilmu agama. Kedua, tidak memiliki strategi penyusunan dan pemilihan materi-materi. Ketiga, kurangnya penjelasan yang luas dan mendalam karena pembelajaran yang kurang berkualitas. ${ }^{9}$

Berkaitan dengan itu, maka dikeluarkanlah kebijakan kurikulum 2013. Perubahan yang sangat mendasar pada kurikulum 2013 adalah materi disusun seimbang mencakup kompetensi sikap, pengetahuan, dan keterampilan. Pendekatan pembelajaran berdasarkan pengamatan, pertanyaan, pengumpulan data, penalaran, dan penyajian hasilnya melalui pemanfaatan berbagai sumber-sumber belajar (peserta didik mencari tahu), dan Penilaian otentik pada aspek kompetensi sikap, pengetahuan, dan keterampilan berdasarkan portofolio.

Titik tekan pengembangan Kurikulum 2013 adalah penyempurnaan pola pikir, penguatan tata kelola kurikulum, pendalaman dan perluasan materi, penguatan proses pembelajaran, dan penyesuaian beban belajar agar dapat menjamin kesesuaian antara apa yang diinginkan dengan apa yang dihasilkan.

${ }^{9}$ Mohammad Ali dalam Abdul Malik, et.al.. 2009. Materi Pembelajaran Mata Kuliah Pengembangan Kepribadian Pendidikan Agama Islam, Jakarta: Departemen Agama, h. xiv-xv.
Model pembelajaran pada kurikulum 2013 diarahkan kepada pembelajaran aktif yang menempatkan pendidik sebagai fasilitator pembelajaran dan menempatkan peserta didik sebagai subjek belajar. Fungsi model pembelajaran PAI adalah sebagai pedoman filosofis perancangan dan pelaksanaan pembelajaran. Pemilihan model sangat dipengaruhi oleh tujuan, mamteri, dan kakrakteristik peserta didik.

Dalam hal penilaian, kurikulum 2013 menghendaki penilaian otentik. Penilaian adalah proses mengumpulkan informasi/ bukti melalui pengukuran, menafsirkan, mendeskripsikan, dan menginterpretasi bukti-bukti hasil pengukuran. Otentik artinya dapat dipercaya, asli, nyata, valid, atau reliabel. Jadi penilaian otentik adalah penilaian yang dilakukan secara komprehensif untuk menilai mulai dari masukan (input), proses, dan keluaran (output) pembelajaran. ${ }^{10}$

Penilaian otentik harus mencerminkan masalah dunia nyata. Menggunakan berbagai cara dan kriteria holistik (kompetensi utuh merefleksikan pengetahuan, keterampilan, dan sikap). Penilaian otentik tidak hanya mengukur apa yang diketahui oleh peserta didik, tetapi lebih menekankan mengukur apa yang dapat dilakukan oleh peserta didik. $^{11}$

${ }^{10}$ Peraturan MenteriPendidikan dan Kebudayaan Republik Indonesia Nomor 66 Tahun 2013 tentang Standar Penilaian.

${ }^{11}$ Permendikbud 81A Tahun 2013, tentang Implementasi kurikulum, 2013, h. 56. 


\section{METODOLOGI PENELITIAN}

Penelitian ini menggunakan pendekatan kualitatif dengan menggunakan dokumen sebagai subjeknya. Dengan pendekatan kualitatif ini, peneliti tetap memposisikan subjek penelitian ini (Buku Pendidikan Agama Islam PTU) berada pada latar belakang alamiahnya. Menurut Moleong salah satu karakteristik penelitian kualitatif adalah berakar pada latar alamiah sebagai keutuhan dan peneliti sebagai instrumen utamanya. ${ }^{12}$

Adapun metode penelitian yang digunakan adalah metode deksriptif. Metode ini digunakan untuk mendeksripsikan serta menganalisis dan menginterpretasi dari data. ${ }^{13}$ Data tersebut dalam penelitian ini adalah subjek penelitian yakni Buku Pendidikan Agama Islam PTUPenerbit Yamiba Jakarta.

Sedangkan instrumen relevansinya menggunakan analisis standar kurikulum 2013 dari Dirjen PAIS Kemenag 2014 yakni: (1) kompetensi (sikap, pengetahuan, dan keterampilan), (2) Pendekaktan pembelajaran berdasarkan pengamatan, pertanyaan, pengumpulan data, penalaran, dan penyajian hasilnya melalui pemanfaatan berbagai sumber-sumber belajar (peserta didik mencari tahu), dan (3) Penilaian otentik pada aspek kompetensi sikap, pengetahuan, dan keterampilan berdasarkan portofolio.

Selanjutnya untuk memperkaya analisisnya digunakan beberapa teori berkaitan dengan instrumen analisis

${ }^{12}$ Lexy Moleong, Metodologi Penelitian Kualitatif, (Bandung: Remadja Rosdakarya, 2000), h. 27.

${ }^{13}$ Winarno Surakhmad. 1998. Pengantar Penelitian Ilmiah: Dasar, Metode dan Teknik, Bandung: Tarsito, Edisi 8, h. 139-140. relevansi. Dengan demikian, hasil analisis yang menyeluruh dan kaya dengan argumen-argumen dari para ahli.

\section{HASIL DAN PEMBAHASAN}

\section{Profil Buku}

\begin{tabular}{lcl}
\hline Judul Buku & $:$ & Pendidikan Agama Islam PTU \\
\hline Penulis & $:$ & Dr. Ali Hamzah, M.Ag \\
\hline Penerbit & $:$ & Yayasan Masyarakat Indonesia Baru (YAMIBA) \\
\hline Tahun Terbit & $:$ & Oktober 2014 \\
\hline Cetakan & $:$ & Kesatu \\
\hline Kota Terbit & $:$ & Jakarta \\
\hline Tebal Buku & $:$ & i-viii dan 246 + Cover \\
\hline Jumlah Bab & $:$ & 14 Bab \\
\hline Harga Buku & $:$ & Rp. 52.000,- \\
\hline ISBN & $:$ & $978-602-9049-31-2$ \\
\hline
\end{tabular}

\section{Garis Besar Intisari Buku}

BAB I PENDIDIKAN AGAMA ISLAM (PAI) DI PERGURUAN TINGGI UMUM (PTU)

A. Pengertian PAI di Perguruan Tinggi Umum

Pendidikan Agama Islam (PAI) pada Perguruan Tinggi Umum (PTU) adalah upaya sadar dan terencana dalam mengembangkan pemahaman, penghayatan, dan pengamalan nilai-nilai ajaran Islam dari sumber utamanya secara tekstual dan kontekstual. Upaya tersebut dilakukan melalui kegiatan pembelajaran, bimbingan, latihan, dan pengalaman yang disampaikan secara dialogis, komprehensif, dan multiperspektif.

B. Visi, Misi, Fungsi, dan Tujuan PAI di PTU

Visi PAI pada PTU adalah menjadi sumber nilai dan pedoman yang mengantarkan mahasiswa dalam mengembangkan keilmuan dan profesinya, serta kepribadian Islami. Adapun misi PAI pada PTU adalah menghasilkan mahasiswa yang beriman, bertakwa, berilmu, dan berakhlak mulia, serta menjadikan ajaran Islam sebagai landasan berpikir dan berperilaku dalam pengembangan keilmuan dan profesi, serta kehidupan bermasyarakat.Hal tersebut bertujuan untuk mewujudkan insan kamil.

C. Pembelajaran dan Penilaian PAI di PTU

Proses pembelajaran PAl harus dillaksanakan dengan pendekatan student centered learning $(\mathrm{SCL})$ dengan pembahasan yang kritis, analisis, induktif, deduktif, dan reflektif.

D. Dasar Hukum dan Tantangan PAI

Dasar hukum adanya mata kuliah PAI pada PTU adalah Undangundang Nomor 20 Tahun 2003 tentang Sistem Pendidikan Nasional. Tantangan PAI pada PTU dalam pembelajaran dengan mengacu pada kurikulum 2013 adalah memahamkan para dosen PAI di PTU agar mampu merubah paradigma PAI yang selama ini hanya bersifat doktrin dalil-dalil, pembelajaran yang berpusat pada dosen, serta diperlukan inovasi-inovasi model dan metode pembelajaran. 
BAB II MENGENAL TUHAN (Rumpun Akidah)

A. Kemampuan Akhir yang Diharapkan

Membuktikan, menerima, dan mengimplementasikan nilai-nilai akidah dalam kehidupan

B. Tugas untuk Mahasiswa

Mahasiswa sebagai tim (kelompok penyaji) mengamati/meneliti dan mendokumentasikan secara detil tentang: (1) proses pertumbuhan suatu tumbuhan (dari mulai biji, kecambah, pohon, daun kering, sampai mati), (2) pergantian siang dan malam, dan (3) keteraturan pertumbuhan dan perkembangan serta fungsi setiap organ fisik manusia dari mulai rambut sampai kaki. Deskripsikan Kemahakuasaan Allah atas ketiga objek tersebut dalam bentuk makalah, slide presentasi, dan abstrak.

C. Proses pembelajaran

Proses pembelajaran dimulai dengan membimbing mahasiswa bertadarus al-Quran Al-An'am ayat 59, kemudian presentasi (kegiatan mahasiswa sebagai: moderator, kelompok penyaji, sesi diskusi, dan asosiasi pembahasan materi dengan dosen sebagai fasilitator. Selanjutnya tahap penguatan atau internalisasi oleh dosen dengan ibrah mauidzah Al-An'am ayat 59 dikaitkan dengan perbuatan mencuri, korupsi, dan lain-lain.

D. Materi Ajar

Materi ajar sebagai referensi untuk membantu mahasiswa mengembangkan materi adalah berkaitan dengan penjelasan ma'rifatullah dan tauhidullah.

BAB III KONSEP MANUSIA DALAM ISLAM (Rumpun Akidah)

A. Kemampuan Akhir yang Diharapkan

Membuktikan, menerima, dan mengimplementasikan nilai-nilai akidah dalam kehidupan

B. Tugas untuk Mahasiswa

Mahasiswa sebagai tim (kelompok penyaji) meneliti, menelaah, dan mendokumentasikan secara detil tentang: (1) foto-foto dan atau video tentang tahapan (fase-fase) pertumbuhan dan perkembangan janin persfektif medis/kedokteran, (2) tahapan penciptaan manusia menurut Quran Surat Al-mu'minun Ayat 12-14, dan (3) Quran Surat Al-Ruum ayat 21 tentang pentingnya membangun keluarga Islami dan Quran Surat Al-An'am ayat 151 tentang larangan membunuh anak (aborsi). Telaah secara mendalam keterkaitannya dalam bentuk makalah, slide presentasi, dan abstrak.

C. Proses Pembelajaran

Proses pembelajaran dimulai dengan membimbing mahasiswa bertadarus al-Quran Surat Al-Mu'minun ayat 12-14, kemudian presentasi (kegiatan mahasiswa sebagai: moderator, kelompok penyaji, sesi diskusi, dan asosiasi pembahasan materi dengan dosen sebagai fasilitator. Selanjutnya tahap penguatan atau internalisasi oleh dosen dengan amtsal mursalahQuran Surat Al$A^{\prime}$ raf ayat 179 dikaitkan dengan pemisalan manusia yang tidak menggunakan potensi.

D. Materi Ajar

Materi ajar sebagai referensi untuk membantu mahasiswa mengembangkan materi adalah berkaitan dengan penjelasan manusia perspektif filsafat barat, manusia perpektif wahyu, hakikat manusia, dan tugas dan fungsi manusia.

\section{BAB IV KEIMANAN DAN KETAKWAAN (Rumpun Akidah) \\ A. Kemampuan Akhir yang Diharapkan \\ Membuktikan, menerima, dan mengimplementasikan nilai-nilai akidah dalam kehidupan \\ B. Tugas untuk Mahasiswa}

Mahasiswa sebagai tim (kelompok penyaji) meneliti dan mendokumentasikan tentang peristiwa teror-teror Bom di Indonesia, mencakup: kapan dan dimana terjadi serta jumlah korban. Kemudian analisis dengan hakikat jihad perspektif Islam. Hasil analisis dibuat laporan dalam bentuk makalah, slide presentasi, dan abstrak.

C. Proses Pembelajaran

Proses pembelajaran dimulai dengan membimbing mahasiswa bertadarus al-Quran Surat Al-Anfal ayat 2-4, kemudian presentasi (kegiatan mahasiswa sebagai: moderator, kelompok penyaji, sesi diskusi, dan asosiasi pembahasan materi dengan dosen sebagai fasilitator. Selanjutnya tahap penguatan atau internalisasi oleh dosen dengan targhibQuran Surat Al-Anfal ayat 2-4 bahwa konteks jihad dalam Islam sangatlah luas sebagai indikator keimanan dan ketakwaan.

D. Materi Ajar

Materi ajar sebagai referensi untuk membantu mahasiswa mengembangkan materi adalah berkaitan dengan penjelasan pengertian iman, proses terbentuknya iman, pengertian takwa, indikator manusia beriman dan bertakwa, dan implementasi iman dan takwa dalam kehidupan.

BAB V AL-QURAN: SUMBER AJARAN ISLAM (Rumpun Syari'ah) Kemampuan Akhir yang Diharapkan

Membuktikan, menerima, dan mengimplementasikan nilai-nilai syari'ah dalam kehidupan

A. Tugas untuk Mahasiswa

Mahasiswa sebagai tim (kelompok penyaji) untuk mengadakan penelitian, menelaah, dan mendokumentasikan tentang perilakuperilaku yang mengindikasikan keresahan dan kegelisahan di masyarakat pada saat ini serta kaji lebih lanjut faktor-faktor yang melatarbelakanginya. (misalnya: baru-baru ini tanggal 21 bulan 12 tahun 2012 dipercaya Suku Maya akan "kiamat" yang menyebabkan keresahan dan kegelisahan di masyarakat. Para orang tua gelisah, manakala menyaksikan perilaku remaja semakin mengkhawatirkan; tawuran, seks bebas, narkoba, dan lain-lain merajalela dimana-mana. Tentu masih banyak yang lainnya). Analisis permasalahan-permasalahan tersebut dengan mengaitkan bahwa Al-quran ibarat "kompas" dan "peta" yang menjadi petunjuk jalan bagi hidup dan kehidupan manusia. Hasil analisis dibuat laporan dalam bentuk makalah, slide presentasi, dan abstrak.

B. Proses Pembelajaran

Proses pembelajaran dimulai dengan membimbing mahasiswa bertadarus al-Quran Surat Al-Baqarah ayat 185, kemudian presentasi (kegiatan mahasiswa sebagai: moderator, kelompok penyaji, sesi diskusi, dan asosiasi pembahasan materi dengan dosen sebagai fasilitator. Selanjutnya tahap penguatan atau internalisasi oleh dosen dengan ibrah mauidzahQuran Surat Al-Baqarah ayat 185 bahwa Quran merupakan petunjuk bagi manusia sehingga mampu membedakan antara hak dan batil, termasuk menjadi pedoman agar mampu mengobati keresahan dan kegelisahan. 


\section{Materi Ajar}

Materi ajar sebagai referensi untuk membantu mahasiswa mengembangkan materi adalah berkaitan dengan penjelasan pengertian al-Quran, Kemukjizatan al-Quran, Kandungan alQuran, al-Quran sebagai Dasar Pengembangan IPTEKS, dan Aktualisasi nilai-nilai al-Quran dalam Kehidupan Modern.

BAB VI HADITS: SUMBER AJARAN ISLAM (Rumpun Syari'ah)

A. Kemampuan Akhir yang Diharapkan

Membuktikan, menerima, dan mengimplementasikan nilai-nilai syari'ah dalam kehidupan

B. Tugas untuk Mahasiswa

Mahasiswa sebagai tim (kelompok penyaji) untuk mengadakan penelitian, menelaah, dan mendokumentasikan tentang penelitian, menelaah, dan mendokumentasikan tentang fenomena masalah maraknya dan meningkatnya pengemis di masyarakat (dilihat dari: usia, jenis kelamin, kondisi fisik, latar belakang (ekonomi) keluarga, alasan, cara dan dimana mengemis). Kemudian lakukan penelitian terhadap Badan Amil Zakat, Infaq, dan Shadaqah (BAZIS) terdekat untuk memperoleh data:sumberpendapatan zakat, dari siapa pendapatan zakat (muzaki), serta bagaimana pengelolaan dan peruntukannya (produktif dan konsumtif). Hasil analisis dibuat laporan dalam bentuk makalah, slide presentasi, dan abstrak.

c. Proses Pembelajaran

Proses pembelajaran dimulai dengan membimbing mahasiswa bertadarus al-Quran Surat Al-Baqarah ayat 273, kemudian presentasi (kegiatan mahasiswa sebagai: moderator, kelompok penyaji, sesi diskusi, dan asosiasi pembahasan materi dengan dosen sebagai fasilitator. Selanjutnya tahap penguatan atau internalisasi oleh dosen dengan tadzkirQuran Surat Al-Baqarah ayat 273 tentang kewajiban ikhtiar dan berusaha menahan untuk tidak meminta-minta/mengemis.

D. Materi Ajar

Materi ajar sebagai referensi untuk membantu mahasiswa mengembangkan materi adalah berkaitan dengan penjelasan Pengertian Hadits, Sejarah Kodifikasi Hadits, Kualifikasi Hadits, Perbedaan al-Quran dan Hadits, dan Fungsi Hadits terhadap alQuran.

BAB VII IJTIHAD: SUMBER PENGEMBANGAN HUKUM ISLAM (Rumpun Syari'ah)

A. Kemampuan Akhir yang Diharapkan

Membuktikan, menerima, dan mengimplementasikan nilai-nilai syari'ah dalam kehidupan

B. Tugas untuk Mahasiswa

Mahasiswa sebagai tim (kelompok penyaji) untuk melakukan studi, menelaah, dan mendokumentasikan tentang kasus berikut: (1) Permohonan untuk melakukan eutanasia pada tanggal 22 Oktober 2004 telah diajukan oleh seorang suami bernama "HK" karena tidak tega menyaksikan istrinya yang bernama "AIN", 33 tahun, tergolek koma selama 2 bulan pasca melahirkan, (2)Face off Lisa, 23 tahun, November 2002, (3) Transplantasi organ tubuh. Kemudian telaah tentang ijtihad dalam Islam untuk menganalisis kasus-kasus tersebut. Hasil penelitian dan analisis dibuat laporan dalam bentuk makalah, slide presentasi, dan abstrak.
C. Proses Pembelajaran

Proses pembelajaran dimulai dengan membimbing mahasiswa bertadarus al-Quran Surat Al-Tiin ayat 1-8, kemudian presentasi (kegiatan mahasiswa sebagai: moderator, kelompok penyaji, sesi diskusi, dan asosiasi pembahasan materi dengan dosen sebagai fasilitator. Selanjutnya tahap penguatan atau internalisasi oleh dosen dengan tarhibQuran Surat Al-Tiin ayat 1-8 bahwa manusia telah diciptakan dengan bentuk yang sempurna.

D. Materi Ajar

Materi ajar sebagai referensi untuk membantu mahasiswa mengembangkan materi adalah berkaitan dengan penjelasan Pengertian dan Ruang Lingkup litihad, Urgensi ljtihad pada Era Globalisasi, Bentuk dan Metodologi ljtihad, dan Dinamika Hasil ljtihad dalam Kehidupan Modern.

BAB VIII HUKUM ISLAM (Rumpun Syari'ah)

A. Kemampuan Akhir yang Diharapkan

Membuktikan, menerima, dan mengimplementasikan nilai-nilai syari'ah dalam kehidupan

B. Tugas untuk Mahasiswa

Mahasiswa sebagai tim (kelompok penyaji) untuk melakukan studi terhadap peraturan, menelaah, dan mendokumentasikan: (1) Undang-undang Nomor 12 Tahun 2012 tentang Pendidikan Tinggi Pasal 28 Ayat (5) dan Pasal 42 Ayat (3) perihal pencabutan gelar akademik dan ijazah atas perilaku plagiat (pengertian, indikator, suatu karya disebut plagiat, menghindari plagiat); (2) Undang-undang Nomor 19 Tahun 2002 tentang Hak Cipta (pengertian, lingkup hak cipta berkaitan dengan pendidikan, proses pendaftaran dan masa berlaku, dan penyelesaian sengketa dan hukum pidana hak cipta); (3) Plagiat dan Hak Cipta persfektif hukum Islam. Hasil studi terhadap peraturan dan analisis dibuat laporan dalam bentuk makalah, slide presentasi, dan abstrak

C. Proses Pembelajaran

Proses pembelajaran dimulai dengan membimbing mahasiswa bertadarus al-Quran Surat Al-Nisa ayat 29, kemudian presentasi (kegiatan mahasiswa sebagai: moderator, kelompok penyaji, sesi diskusi, dan asosiasi pembahasan materi dengan dosen sebagai fasilitator. Selanjutnya tahap penguatan atau internalisasi oleh dosen dengan ibrah mauidzah yang berkaitan dengan Quran Surat Al-nisa Ayat 29 bahwa dilarang "mencuri" harta. Harta mengandung makna sangat luas, termasuk karya dan hak cipta. Karena itu, sangat dilarang melakukan plagiat karena termasuk jalan yang batil.

D. Materi Ajar

Materi ajar sebagai referensi untuk membantu mahasiswa mengembangkan materi adalah berkaitan dengan penjelasan Pengertian dan Ruang Lingkup Hukum Islam, Tujuan Hukum Islam, Fungsi Hukum Islam dalam Kehidupan, dan Aktualisasi Hukum Islam di Indonesia.

BAB IX ETIKA, MORAL, DAN AKHLAK (Rumpun Akhlak)

A. Kemampuan Akhir yang Diharapkan

Membuktikan, menerima, dan mengimplementasikan nilai-nilai akhlak Islami dalam kehidupan 
B. Tugas untuk Mahasiswa

Mahasiswa sebagai tim (kelompok penyaji) untuk menelaah kasus-kasus berikut: (1) "Survei KPA terhadap 4.500 remaja di 12 kota besar seluruh Indonesia, menemukan $97 \%$ pernah mengakses pornografi, 93\% pernah berciuman, dan $62,7 \%$ pernah berhubungan badan, dan $21 \%$ remaja telah melakukan aborsi (Sumber: Menkominfo, dalam HU. Kompas, 10 Mei 2010)"; (2)Badan Narkotika Nasional (2006) menyebutkan bahwa 80 $\%$ dari sekitar 3,2 pengguna berasal dari kelompok usia muda (remaja/pemuda) (Sumber: Blog Komisi Nasional Perlindungan Anak); (3) Alwi Yusianto Putra, siswa kelas X SMA Negeri 6, telah menjadi korban tawuran (September, 2012). Analisis kasuskasus tersebut mencakup: fakor-faktor penyebab, dampak yang ditimbulkan (sisi medis dan sosial), alternatif yang ditawarkan kelompok untuk meminimalisir dan mencegah permasalahn tersebut. Analisis dikaitkan dengan kata hikmah: "Masa depan suatu bangsa berada di tangan pemuda". Hasil penelaahan kasus dan analisis dibuat laporan dalam bentuk makalah, slide presentasi, dan abstrak.

C. Proses Pembelajaran

Proses pembelajaran dimulai dengan membimbing mahasiswa bertadarus al-Quran Surat Al-Taubah ayat 105, kemudian presentasi (kegiatan mahasiswa sebagai: moderator, kelompok penyaji, sesi diskusi, dan asosiasi pembahasan materi dengan dosen sebagai fasilitator. Selanjutnya tahap penguatan atau internalisasi oleh dosen dengan targhib wa tarhibyang berkaitan dengan Quran Surat Al-Taubah Ayat 105 tentang wajibnya berusaha terutama optimalisasi masa muda

D. Materi Ajar

Materi ajar sebagai referensi untuk membantu mahasiswa mengembangkan materi adalah berkaitan dengan penjelasan Konsep Etika, Moral, dan Akhlak, Karakteristik Etika Islam, Hubungan Tasawwuf dengan Akhlak, Indikator Manusia Berakhlak, dan Akhlak dan Aktualisasinya dalam Kehidupan.

BAB X KERUKUNAN INTER DAN ANTAR UMAT BERAGAMA (Aktualisasi Ajaran Islam)

A. Kemampuan Akhir yang Diharapkan

Menganalisis, menerima, dan mengaktualisasikan ajaran Islam dalam kehidupan.

B. Tugas untuk Mahasiswa

Mahasiswa sebagai tim (kelompok penyaji) untuk melakukan studi naskah, menelaah, dan mendokumentasikan tentang PIAGAM MADINAH dikontekstualisasikan dengan kerukunan inter dan antar umat beragama di Indonesia (mencakup: pentingnya akidah sebagai dasar, pembentukkan umat, kewajiban dan hak asasi manusia, persatuan segenap warga, golongan minoritas, tugas warga negara, dan timbulnya rasa aman dan nyaman dengan lahirnya suatu peraturan). Hasil studi naskah dan analisis dibuat laporan dalam bentuk makalah, slide presentasi, dan abstrak.
C. Proses Pembelajaran

Proses pembelajaran dimulai dengan membimbing mahasiswa bertadarus al-Quran Surat Al-Hujurat ayat 11, kemudian presentasi (kegiatan mahasiswa sebagai: moderator, kelompok penyaji, sesi diskusi, dan asosiasi pembahasan materi dengan dosen sebagai fasilitator. Selanjutnya tahap penguatan atau internalisasi oleh dosen dengan hiwar jadali yang berkaitan dengan Quran Surat Al-Hujurat ayat 11 dan Surat Al-Kafirun ayat 1-6 tentang pentingnya membina dan menjaga kerukunan inter dan antar umat beragama dalam konteks Indonesia yang dalam segala aspek kehidupan sangat beragam.

D. Materi Ajar

Materi ajar sebagai referensi untuk membantu mahasiswa mengembangkan materi adalah berkaitan dengan penjelasan Pengertian dan Ruang Lingkup Kerukunan Hidup Umat Beragama, Konsep Persaudaraan dalam Islam, Implementasi Toleransi dalam kehidupan, dan Implementasi Toleransi dalam Kehidupan Bermasyarakat, Berbangsa, dan Bernegara.

BAB XI EKONOMI SYARI'AH (Aktualisasi Ajaran Islam)

A. Kemampuan Akhir yang Diharapkan

Menganalisis, menerima, dan mengaktualisasikan ajaran Islam dalam kehidupan.

B. Tugas untuk Mahasiswa

Mahasiswa sebagai tim (kelompok penyaji) untuk melakukan penelitian komparasi, menelaah, dan mendokumentasikan tentang: (1) Dasar hukum dan produk-produk bank konvensional dan bank syari,ah; (2) Keputusan ljtima' Ulama Komisi Fatwa SeIndonesia Tanggal 16 Desember 2003, melalui MUI ditetapkan Surat Keputusan bahwa Bunga Bank termasuk riba nasi'at, dari aspek bagian: pengertian bunga bank, hukum bunga bank, hukum bermuamalah dengan bank konvensionalserta dasardasar penetapan fatwa. Hasil penelitian dan analisis dibuat laporan dalam bentuk makalah, slide presentasi, dan abstrak.

C. Proses Pembelajaran

Proses pembelajaran dimulai dengan membimbing mahasiswa bertadarus al-Quran Surat Al-Ruum ayat 39, kemudian presentasi (kegiatan mahasiswa sebagai: moderator, kelompok penyaji, sesi diskusi, dan asosiasi pembahasan materi dengan dosen sebagai fasilitator. Selanjutnya tahap penguatan atau internalisasi oleh dosen dengan targhib wa tarhib Quran Surat Al-Ruum ayat 39 adalah balasan riba dan balasan zakat di sisi Allah.

D. Materi Ajar

Materi ajar sebagai referensi untuk membantu mahasiswa mengembangkan materi adalah berkaitan dengan penjelasan Pengertian dan Ruang Lingkup Ekonomi Syari'ah, Perbedaan Sistem Ekonomi Syari'ah dengan Sistem Ekonomi Lainnya, dan Perbankan Syari'ah.

BAB XII SISTEM POLITIK ISLAM (Aktualisasi Ajaran Islam)

A. Kemampuan Akhir yang Diharapkan

Menganalisis, menerima, dan mengaktualisasikan ajaran Islam dalam kehidupan. 
B. Tugas untuk Mahasiswa

Mahasiswa sebagai tim (kelompok penyaji) untuk meneliti, menelaah, dan mendokumentasikan tentang proses pengangkatan ke empat khalifah (Abu Bakar Ibn Shiddiq, Umar Ibn Khaththab, Utsman Ibn Affan, dan Ali Ibn Abu Thalib). Kemudian komparasikan dengan sistem pengangkatan presiden di Indonesia. Hasil penelitian dan analisis dibuat laporan dalam bentuk makalah, slide presentasi, dan abstrak.

c. Proses Pembelajaran

Proses pembelajaran dimulai dengan membimbing mahasiswa bertadarus al-Quran Surat Al-Nisa ayat 59, kemudian presentasi (kegiatan mahasiswa sebagai: moderator, kelompok penyaji, sesi diskusi, dan asosiasi pembahasan materi dengan dosen sebagai fasilitator. Selanjutnya tahap penguatan atau internalisasi oleh dosen dengan ibrah mauidzahQuran Surat Al-nisa Ayat 59 adalah ketaatan kepada Allah, Rasul, dan pemimpin.

D. Materi Ajar

Materi ajar sebagai referensi untuk membantu mahasiswa mengembangkan materi adalah berkaitan dengan penjelasan Pengertian Politik Islam, Ruang Lingkup Sistem Politik Islam, Demokrasi dan Musyawarah, dan Implementasi Politik Islami dalam Kehidupan Berbangsa dan Bernegara.

BAB XIII KEBUDAYAAN ISLAM (Aktualisasi Ajaran Islam)

A. Kemampuan Akhir yang Diharapkan

Menganalisis, menerima, dan mengaktualisasikan ajaran Islam dalam kehidupan.

B. Tugas untuk Mahasiswa

Mahasiswa sebagai tim (kelompok penyaji) untuk membuat blog dengan tampilan menarik untuk memasukkan kajiankajian Keislaman yang mencakup:aqidah, syari'ah, dan akhlak, serta aktualisasi Islam dan isu-isu PTU.Hasil pembuatan blog dipresentasikan. Buat pula laporan berbentuk makalah yang terlebih dahulu membahas kajian teori tentang IPTEKS perspektif Islam dan implementasinya bagi kehidupan.

C. Proses Pembelajaran

Proses pembelajaran dimulai dengan membimbing mahasiswa bertadarus al-Quran Surat Al-Rahman ayat 33, kemudian presentasi (kegiatan mahasiswa sebagai: moderator, kelompok penyaji, sesi diskusi, dan asosiasi pembahasan materi dengan dosen sebagai fasilitator. Selanjutnya tahap penguatan atau internalisasi oleh dosen dengan targhib Quran Surat Al-rahman ayat 33 adalah keharusan mengembangkan IPTEKS ke arah lebih maju dan manfaat.

D. Materi Ajar

Materi ajar sebagai referensi untuk membantu mahasiswa mengembangkan materi adalah berkaitan dengan penjelasan Pengertian Kebudayaan, Kebudayaan Islam, dan Ruang Lingkupnya, Sejarah Peradaban Islam, dan IPTEKS dalam Islam.

BAB XIV FUNGSI MASJID (Aktualisasi Ajaran Islam)

A. Kemampuan Akhir yang Diharapkan

Menganalisis, menerima, dan mengaktualisasikan ajaran Islam dalam kehidupan.
B. Tugas untuk Mahasiswa

Mahasiswa sebagai tim (kelompok penyaji) untuk melakukan penelitian tentang fenomena "penyempitan" fungsi masjid. Kemudian mengkaji tentang pemberdayaan umat berbasis masjid, mencakup: Idarah (manajemen perkantoran masjid), Imarah (manajemen kepemimpinan/SDM masjid), Ri'ayah (kegiatan memakmurkan/gebyar masjid termasuk tarbiyah (pendidikan) dan Baitul Maal Masjid). Hasil penelitian dan analisis dibuat laporan dalam bentuk makalah, slide presentasi, dan abstrak.

C. Proses Pembelajaran

Proses pembelajaran dimulai dengan membimbing mahasiswa bertadarus al-Quran Surat Al-Taubah ayat 18, kemudian presentasi (kegiatan mahasiswa sebagai: moderator, kelompok penyaji, sesi diskusi, dan asosiasi pembahasan materi dengan dosen sebagai fasilitator. Selanjutnya tahap penguatan atau internalisasi oleh dosen dengan targhib Quran Surat Al-nisa ayat 18 adalah keberkahan bagi orang-orang yang memakmurkan masjid.

D. Materi Ajar

Materi ajar sebagai referensi untuk membantu mahasiswa mengembangkan materi adalah berkaitan dengan penjelasan Pengertian Masjid, Sejarah Masjid, dan Fungsi Masjid.

\section{Relevansi Buku PAI PTU Dilihat dari Komponen Kompetensi Akhir yang Diharapkan (Learning Outcome)}

Dilihat dari komponen kompetensi akhir yang diharapkan (learning outcome) dalam buku PAI PTU yang di susun oleh Dr. Ali Hamzah, M.Ag diterbitkan oleh penerbit Yamiba Jakarta ini telah memenuhi standar kurikulum 2013. Kompetensi yang terdapat Buku PAI PTU ini mencakup pada empat kompetensi yakni: 1) Membuktikan, menerima, dan mengimplementasikan nilai-nilai akidah dalam kehidupan; 2) Membuktikan, menerima, dan mengimplementasikan nilai-nilai syari'ah dalam kehidupan; 3) Membuktikan, menerima, dan mengimplementasikan nilai-nilai akhlak Islami dalam kehidupan; dan 4) Menganalisis, menerima, dan mengaktualisasikan ajaran Islam dalam kehidupan.

Dari keempat poin kompetensi di atas, benang merah learning outcome-nya 
mencakup pada aspek akidah, syariah, akhlak, dan aktualisasi ajaran Islam. Hal tersebut sesuai dengan ruang lingkup dinul Islam yakni aqidah, syariah, dan akhlak. Di samping itu aktualisasi ajaran Islam sangat diperlukan dalam konteks kekinian.

Pentingnya keseimbangan learning outcomeyangmencakupempataspektersebut ditegaskan oleh Mohammad Ali dalam rangka memecahkan masalah kesenjangan antara retorika dan ajaran Islam yang begitu ideal dan realitas sosial yang timbul akhirakhir ini. ${ }^{14}$ Pendidikan agama Islam bukan saja masalah penguasaan ilmu-ilmu agama, namun juga harus menyentuh ke masalah sikap dan diimplementasikan dalam bentuk akhlak.Dalam kerangka ruang lingkup PAI yakni keserasian, keselarasan, dan keseimbangan antara hubungan manusia dengan Allah, hubungan manusia dengan dirinya sendiri, hubungan manusia dengan sesama manusia, dan hubungan manusia dengan makhluk lain dan lingkungan alam. ${ }^{15}$

Learning outcome sebagaimana yang terdapat dalam buku ini sesuai dengan pendapat Harun Nasution bahwa pendidikan agama Islam di sekolah umum bertujuan untuk membentuk manusia takwa yakni manusia yang patuh kepada Allah dalam menjalankan ibadah dengan menekankan pembinaan kepribadian muslim. Artinya manusia yang dimanapun dia berada sesuai dengan tujuan diturunkannya Islam. ${ }^{16}$

${ }^{14}$ Dalam Abdul Malik, et.al.,Materi Pembelajaran Mata Kuliah Pengembangan Kepribadian Pendidikan Agama Islam ...h. Xiii.

15 Syahidin, et.al.,Pendidikan Agama Islam PTU, (Jakarta: Yamiba, 2014), h. 3.

16 Syahidin, et.al., Moral dan Kognisi Islam, (Bandung: Alfabeta, 2009), h. 11-12.
Tentunya untuk membentuk kepribadian muslim yang utuh (al-insan alkamil) harus dimulai dengan keyakinan yang kuat. Keyakinan itu diimplementasikan dalam ketaatan ibadah dan akhlak. Sekaitan kompetensi yang harus dimiliki mahasiswa, maka Buku Pendidikan Agama Islam PTUPenerbit Yamiba Jakarta ini relevan dengan kurikulum 2013. Relevansi tersebut sebagaimana standar kompetensi PAI dalam kurikulum 2013 yakni mahasiswa memiliki kompetensi sikap, pengetahuan, dan keterampilan. Di samping itu argumen relevansi tersebut didasarkan pula pada pendapat para pakar mengenai tujuan pendidikan agama Islam.

\section{Relevansi Buku PAI PTU Dilihat dari Komponen Proses Pembelajaran atau Perkuliahan}

Ciri utama proses pembelajaran pada kurikulum 2013 adalah student centered learning (pembelajaran berpusat pada mahasiswa). Dalam hal ini mahasiswa adalah subjek belajar sedangkan dosen adalah fasilitator belajar. Di dalam Buku Pendidikan Agama Islam PTU yang disusun Ali Hamzah, terdapat sub tugas untuk mahasiswa dan proses pembelajaran. Berikut pembahasannya:

Kesatu, Tugas untuk Mahasiswa. Dalam sub ini sebagaimana terdapat dalam buku yang diteliti memuat tugas kepada mahasiswa yang dibentuk dalam kelompok (tim) untuk meneliti, menelaah, mengamati, dan mendokumentasikan tentang suatu objek (berupa masalah, kejadian sejarah, kejadian aktual). Hal tersebut sesuai dengan model pembelajaran berbasis masalah dimana mahasiswa secara berkelompok 
menggali pengalaman-pengalaman belajar. ${ }^{17}$ Hasilnya dibuat dalam bentuk makalah, slide presentasi, dan abstrak. Di sinilah mahasiswa menggali dan membangun pengetahuannya secara mandiri dengan guide line dari dosen.

Kedua, Proses Pembelajaran. Dalam buku yang diteliti proses pembelajaran menempuh tahap: 1) Tahap mahasiswa bertadarus al-Quran; 2) Tahap presentasi dengan pembagian tugas sebagai penyaji, audien, dan moderator yang memimpin jalannya presentasi. Dosen dalam presentasi ini adalah sebagai fasilitator; dan 3) Tahap penguatan/internalisasi nilai-nilai Quran dan materi yang telah dibahas.

Proses pembelajaran dalam buku yang diteliti menggunakan pendekatan yang berpusat pada mahasiswa (student centered learning). Strategi pembelajarannya adalah mahasiswa meneliti, menelaah, mengamati, dan mendokumentasikan serta mengkontruksi pengalaman belajarnya secara mandiri (discovery learning) yang kemudian dikomunikasikan kepada kelas.

Strategi pembelajaran demikian sesuai dengan beberapa teori dalam belajar. Misalnya teori belajar humanistik yang hakikatnya bahwa belajar harus berpusat kepada peserta didik (learner centered). ${ }^{18}$ Dalam teori humanistik ini siswa mempersepsi pengalaman belajarnya sendiri dan menginternalisasi pengalaman belajar tersebut ke dalam dirinya secara aktif.

17 Lebih lanjut tentang model pembelajaran berbasis masalah bisa dibaca pada buku karangan: Agus Suprijono, Cooperative Learning Teori dan Aplikasi PAIKEM, (Yogyakarta: Pustaka Pelajar, 2013), h. 68-73.

18 Abdorrakhman Gintings, 2010. Esensi Praktis Belajar dan Pembelajaran, Bandung; Humaniora, hlm. 29.
Teori lainnya adalah konstruktivistik. Teori ini memandang bahwa peserta didik memiliki kemampuan untuk mengkontruksi sendiri dengan jalan berinteraksi secara terus menerus dengan lingkungannya. ${ }^{19}$

Apabila dikonfirmasikan dengan standar proses pembelajaran dalam kurikulum 2013 yang menekankan pada dasar pengamatan, pertanyaan, pengumpulan data, penalaran, dan penyajian hasilnya melalui pemanfaatan berbagai sumbersumber belajar (peserta didik mencari tahu), maka proses pembelajaran yang diterapkan dalam buku Pendidikan Agama Islam PTU ini relevan. Pun memiliki relevansi dengan teori-teori belajar yang praktiknya berpusat pada mahasiswa (student centered learning).

\section{Relevansi Buku PAI PTU Dilihat dari Komponen Penilaian}

Perubahan yang sangat mendasar pada kurikulum 2013 dalam hal penilaian adalah penilaian otentik pada aspek sikap, pengetahuan, dan keterampilan berdasarkan portofolio. Instrumen yang dikembangkan tentunya harus mengacu pada ketiga aspek penilaian tersebut.

Dalam Buku Pendidikan Agama Islam PTU yang disusun Ali Hamzah ini pada halaman 7-11 dijelaskan tentang penilaian pembelajaran PAI pada PTU. Penjelasannya berkaitan dengan pengertian dan fungsi penilaian PAI pada PTU, yaitu: 1) Ruang lingkup penilaian PAI pada PTU; 2) Ketentuan penilaian PAI pada PTU, yang mengacu pada ranah dan rentang penilaian kognitif (pengetahuan), apektif (sikap), dan motorik (keterampilan); 3) Prinsip penilaian

\footnotetext{
${ }^{19}$ Ibid., h. 30.
} 
PAI pada PTU yang mencakup: sahih, objektif, adil, terpadu, terbuka, menyeluruh dan berkesinambungan, sistematis, beracuan kriteria, akuntabel, mendidik, dan bermakna; 4) Jenis dan instrumen penilaian PAI pada PTU meliputi: tes dan non tes;

\section{Mekanisme dan Prosedur Penilaian PAI pada PTU}

Apabila ditelaah secara mendalam dalam Buku yang diteliti, proses penilaiannya mencakup pada penilaian proses dan penilaian hasil. Penilaian proses menekankan pada proses belajar mahasiswa, sedangkan penilaian hasil mengacu pada standar kompetensi yang dimiliki mahasiswa setelah mengikuti proses pembelajaran. Penekanan penilaian proses dan hasil ini sesuai dengan pendapat Widjajanto bahwa penilaian dilakukan untuk mengetahui seberapa jauh program dapat mencapai tujuan yang telah ditetapkan. Penilaian dilakukan pada dua aspek yakni proses dan hasil. Penilaian proses dilakukan apakah proses berjalan sesuai rencana. Sedangkan penilaian hasil dilakukan untuk mengetahui efektivitas proses dalam mencapai tujuan yang telah ditetapkan. ${ }^{20}$

Apabila dikonfirmasikan dengan standar penilaian pada kurikulum 2013, pembahasan penilaian pada Buku Pendidikan Agama Islam PTU yang diteliti cukup relevan. Namun demikian, dalam buku yang diteliti ini penilaian hanya ditemui pada BAB I saja yang menurut hemat peneliti masih bersifat umum. Peneliti tidak menemukan penilaian secara khusus setiap bab. Pun tidak ditemukan instrumen untuk menilai

${ }^{20}$ Kenmada, Widjajanto, et.al.. 2013. Perencanaan Komunikasi, Konsep dan Aplikasi. Bandung: Ultimus. sikap, pengetahuan, dan keterampilan dalam setiap babnya. Dengan demikian, pada bagian ini merupakan kelemahan dari Buku Pendidikan Agama Islam PTU yang disusun Dr. Ali Hamzah, yang harus diperbaiki pada edisi selanjutnya.

\section{PENUTUP}

Dari hasil penelitian dan pembahasan tentang:Studi Relevansi Buku PAI PERGURUAN TINGGI UMUM dengan Kurikulum 2013 (Studi Kasus pada Buku Pendidikan Agama Islam PTU penerbit Yamiba Jakarta), dapat disimpulkan sebagai berikut: (1) Dilihat dari komponen kompetensi sebagai Learning Outcome perkuliahan PAI pada PTU, buku yang diteliti memiliki relevansi dengan kurikulum 2013 karena mengacu kompetensi mahasiswa pada aspek sikap, pengetahuan, dan keterampilan yang diimplementasikan dalam akhlak karimah. Relevansi itu diperkuat dengan pendapat para pakar mengenai tujuan pendidikan agama Islam; (2) Dilihat dari proses pembelajaran, buku yang diteliti relevan dengan kurikulum 2013 dengan pembelajaran yang berpusat pada mahasiswa (student centered learning). Dalam buku yang diteliti dijelaskan tahapan dalam proses pembelajaran yang dimulai dengan mahasiswa membangun sendiri pengalaman belajarnya melalui kegiatan meneliti, mengamati, menelaah serta didokumentasikan dalam bentuk laporan. Laporan itu kemudian dikomunikasikan di kelas. Tugas dosen dalam pembelajaran adalah fasilitator dan menginternalisasikan nilai-nilai Quran dan materi yang telah diberikan; (3) Dilihat dari penilaian berdasar standar kurikulum 2013, buku yang diteliti 
belum cukup relevan. Dalam buku yang diteliri hanya dijumpai penilaian dalam pembahasan umum dalam Bab I, tidak menekankan pada setiap babnya, baik bentuk maupun instrumennya.

Hasil studi ini merekomendasikan bahwa: (1) Buku Pendidikan Agama Islam PTU Penerbit Yamiba Jakarta dapat layak dipergunakan sebagai buku teks mata kuliah PAI pada PTU, (2) Untuk menyempurnakan buku teks ini, diperlukan perbaikan pada komponen penilaian, sehingga harus ada edisi revisi.

\section{UCAPAN TERIMA KASIH}

Naskah ini merupakan hasil telaah naskah buku Pendidikan Agama Islam (PAI) Perguruan Tinggi Umum, yang penulis lakukan pada tahun 2015 atas biaya dari Puslitbang Pendidikan Agama dan Keagamaan. Penelitian ini melibatkan berbagai pihak, oleh karena itu penulis ingin menyapaikan penghargaan dan terimakasih kepada Kepala Puslitbang Pendidikan Agama dan Keagamaan yang telah memberikan pengarahan dan pembinaan sehingga kegiatan ini berjalan lancar. Selanjutnya kepada Dr. Ali Hamzah, M.Ag selaku penulis buku yang telah membantu dalam pengumpulan data dan informasi sehingga naskah ini bisa hadir dalam edisi jurnal, kepada Penerbit buku Yayasan Masyarakat Indonesia Baru (Yamiba) Jakarta dan Serta seluruh pihak yang ikut membantu, baik secara langsung maupun tidak langsung. Penulis hanya bisa berdoa, semoga Allah membalas kebaikan-kebaikan mereka dengan setimpal.Amin. Taklupa Penulisjuga mengucapkan terimaksih kepada redaksi jurnal Edukasi yang telah memuat tulisan ini sehingga dapat dibaca para pembaca, penulis menyadari sepenuhnya bahwa naskah ini masih terdapat kekurangan dan kesalahan dalam penulisan, kritik dan saran kami hargai demi penyempurnaan penulisan yang akan datang. besar harapan penulis, semoga naskah ini dapat bermanfaat dan dapat bernilai positif bagi semua pihak yang membutuhkan.

\section{DAFTAR PUSTAKA}

Amin, Rifqi. (2015): Pengembangan Pendidikan Agama Islam, Yogjakarta: LKiS

Departemen Pendidikan Nasional (Depdiknas) Nomor 43 Tahun 2006 Tentang Rambu-Rambu Pelaksanaan Kelompok Mata Kuliah Pengembangan Kepribadian di Perguruan Tinggi.

Direktorat Jenderal Pendidikan Islam Direktorat Pendidikan Agama Islam Kementerian Agama. 2014.Pedoman Umum Implementasi Kurikulum 2013 Pendidikan Agama Islam dan Budi Pekerti pada Sekolah Dasar (SD), Jakarta: Dirjen PAIS Kemenag.

Gintings, Abdorrakhman. (2010): Esensi Praktis Belajar dan Pembelajaran, Bandung; Humaniora.

Harto, Kasinyo. (2012): Model Pengembangan Pendidikan Agama Islam, Jakarta; Rajawali Press

Kbbi.web.id/relevansi.Pengertian Relevansi, Diakses 17 Desember 2015.

Majid, Abdul dan Dian Andayani. (2005): Pendidikan Islam Berbasis Kompetensi, Bandung; Remaja Rosda Karya. 
Malik, Abdul, et.al. (2009): Materi Pembelajaran Mata Kuliah Pengembangan Kepribadian Pendidikan Agama Islam, Jakarta: Departemen Agama.

Marimba, Ahmad D. (1968): Pengantar Filsafat Pendidikan Islam, Bandung; Al-Ma'arif.

Moleong, Lexy. (2000): Metodologi Penelitian Kualitatif, Bandung; Remadja Rosda Karya.

Peraturan Menteri Pendidikan dan Kebudayaan Republik Indonesia Nomor 66 Tahun 2013 tentang Standar Penilaian.

Permendikbud 81A Tahun 2013. tentang Implementasi kurikulum.

Suprijono, Agus. (2013): Cooperative Learning Teori dan Aplikasi PAIKEM, Yogyakarta; Pustaka Pelajar.
Surakhmad, Winarno. (1998): Pengantar Penelitian Ilmiah: Dasar, Metode dan Teknik, Bandung; Tarsito.

Syahidin, et.al. (2009): Moral dan Kognisi Islam, Bandung; Alfabeta.

Syahidin, et.al. (2014): Pendidikan Agama Islam PTU, Jakarta; Yamiba.

Tarigan, Henry Guntur. (1986): Menulis sebagai Suatu Keterampilan Berbahasa, Bandung; Angkasa.

Uhbiyati, Nur. (1997): Ilmu Pendidikan Islam, Bandung; Pustaka Setia.

Undang-Undang Nomor 20 Tahun 2003 tentang Sistem Pendidikan Nasioanl, Bab IV, Pasal 9.

Widjajanto, et. al. (2013): Perencanaan Komunikasi, Bandung: Ultimus. 